\title{
MENANGKAL RADIKALISME MELALUI PENDIDIKAN AGAMA ISLAM BERBASIS ASWAJA NAHDLATUL ULAMA'
}

\author{
Muhammad Husnur Rofiq ${ }^{1}$, Riza Ahmad Ridwan² \\ Institut Pesantren KH Abdul Chalim Mojokerto \\ e-mail: 1umasoviq@gmail.com , ${ }^{2}$ Rizaahmad611@gmail.com
}

Diterima: 10 Mei 2019 | Direvisi: 27 Mei 2019 Disetujui: 27 Mei 2019

(C) 2018 Program Studi Pendidikan Agama Islam Fakultas Agama Islam Universitas Islam Malang

\begin{abstract}
One education that can provide values in counteracting radicalism is Islamic education based on Nahdlatul Ulama. Because Nahdlatul Ulama 'based Islamic education gives more value to education. Nahdlatul Ulama-based Islamic education is flexible in dealing with a situation and condition that exists in society. This research method uses library research which analyzes problems from several books, journals, and relevant scientific publications. The results of this study indicate that the educational process to counteract radicalism is with the approach of Islamic religious education based on Nahdatul Ulama. community values are internalized so that they are tolerant (tasamuh) towards others or others.
\end{abstract}

Keyword: Islamic Education, Aswaja NU, Radicalism

\section{Pendahuluan}

Indonesia merupakan negara yang memiliki beragam pulau, suku, dan budaya. Indonesia juga negara yang memiliki lima agama, yaitu Islam, Kristen, Katolik, Hindu, dan Budha yang mayoritas penduduknya memeluk agama Islam. Meskipun di dominasi oleh penganut agama Islam, Indonesia dikenal sangat damai dan menjunjung tinggi toleransi. Masyarakat Indonesia juga mayoritas masih mempercayai ajaran nenek moyangnya. Namun ajaran tersebut telah di masuki oleh ajaran Islam. jadi tidak heran jika agama Islam di Indonesia berbeda dengan lainnya. Karena agama Islam di Indonesia telah bercampur dengan agama. Namun dibalik itu, banyak yang menentang budaya dan tradisi Islam di Indonesia. Padahal perintis dari ajaran dan tradisi di Indonesia adalah Wali Songo. Wali Songo merupakan ulama' yang datang dari timur tengah dan tak perlu diragukan lagi tentang keilmuannya.

Akhir-akhir ini memang sangat banyak sekte-sekte, aliran-aliran, dan madzhab-madzhab baru yang mengatasnamakan Islam. mereka mengaku sangat berpegang teguh dengan Al Qur'an dan Hadist nabi saja. Sehingga apapun yang tidak sesuai dengan Al Qur'an dan Hadist maka itu dianggap 
bid'ah dan sesat. Dan yang lebih perah lagi, mereka memahami Al Qur'an dan hadist dengan kontekstual saja. Mereka lebih suka memahami teks-teks terjemahan dari suatu kitab hadist dan al Qur'an tanpa mengetahui asbabul nuzul dan asbabul wurud. Hal ini, tentu menjadikan faham-faham yang salah dan berakibat pada perbuatan-perbuatan yang diskriminatif.

Sikap anti mereka yang terlalu berlebihan, akhirnya melahirkan radikalisme. Hal ini menyebabkan seolah-oleah Islam sangat tidak menghargai atas sebuah perbedaan dan juga Islam akan lebih dikenal suka akan sebuah peperangan. Hal ini dapat dibuktikan dengan aksi mereka yang merusak makam-makam dan situs-sius yang bersejarah. Karena menurut mereka, tempat tempat seperti itu akan menjadi sarang khurafat. Mereka juga membunuh dengan cara yang tidak manusiawi yitu dengan bom. Karena mereka berkeyakinan bahwa orang kafir, orang yang berbuat dosa besar maka wajib di bunuh. Mereka melakukan itu semua atas nama "Jihad Di Jalan Allah" dengan mengharap mati dengan khusnul khotimah. Padahal Islam sangat mengajarkan saling menghargai, menghormati, menjunjung tinggi toleransi. Hal ini telah diajarkan oleh Nabi Muhammad Saw. Salah satu kelompok yang masih mempertahankan tradisi dan budaya adalah Nahdlatul Ulama'. Oleh karena itu banyak kelompok-kelompok yang menentang faham dan kegiatan yang dilakukan oleh Nahdlatul Ulama'. Nahdlatul Ulama' sendiri adalah sebuah kelompok yang berfaham Ahlussunnah wal Jama'ah.

Oleh karena itu, peran pendidikan dalam menangkal radikalisme di Indonesia sangat penting. Maka menarik untuk dikaji tentang problematika yang telah dijelaskan diatas. Maka disini penulis mengangkat judul "Menangkal Radikalisme Melalui Pendidikan Agama Islam Berbasis Nahdlatul Ulama". Karena dari sini kita dapat mengetahui ajaran-ajaran yang menjunnung tinggi nilai perdamaian dan toleransi agar dapat memahami sebuah perbedaan yang ada di Indonesia.

\section{Pembahasan}

\section{Radikalisme}

Radikalisme secara bahasa berasal dari radikal yang memiliki arti menyeluruh, habis-habisan, amat keras dalam menuntut perubahan (undang-undang, pemerintah, dsb). Dalam bahasa Inggris, radikal memiliki makna fanatik, ekstrim, fundamental, revolusioner (Jauhari, 2018: 2). Sedangkan radikalisme dapat diartikan sebagai paham yang menganut pola radikal dalam berpolitik (Dendy, 2008: 1246).

Sedangkan secara istilah, radikalisme agama berarti sebuah perilaku yang menyalahi syariat agama, bertindak sangat keras dalam sesuatu pertikaian antara dua pihak, menyetujui dalam mengubah situasi-situasi 
sosial dengan tindakan-tindakan yang menyalahi sayriat agama (Tim Aswaja, 2016: 374).

Dalam agama Islam, radikalisme pertama kali muncul dari kelompok khawarij. Karena khawaijlah yang pertama kali menanamkan bibit-bibit radikalisme (Tim Aswaja, 2016: 376). Hal ini timbul karena sikap khawarij yang terlalu berlebihan membenci pada Sayyidina Ali dan beberapa sahabat pada saat perang siffin. Bahkan mreka menganggap bahwa para sahabat yang mnyetujui perdamaian dalam perang itu dianggapnya sebagai kafir. Sikap radikal mereka juga dibuktukan dengan mereka memaksakan pendapatnya agar disetujui oleh pihak lain.

Pada masa Nabi Muhammad Saw masih hidup, kondisinya damai dan tentram. Namun, kondisi ini semakin menurun setelah Nabi Muhammad Saw meninggal. Pertentangan-pertentangan dan perbedaan-perbedaan antar sesama umat islam kerap terjadi. Hal ini berlangsung dari khakifah Abu Bakar As Shiddiq hingga puncaknya pada Khalifah Ali bin Abi Thalib. Pertikaian tersebut ditandai dengan perang Jamal antara Ali dan kelompok Thalhah, Zubair, dan Aisyah. Pertempuran ini pada akhirnya dimenangkan oleh Ali. Setelah perang jamal terjadi, tidak lama kemudian, terjadilah perang siffin yang melibatkan antara Sayyidina Ali dan kelompok Muawiyah yang mana Muawiyah menjabat sebagi gurbenur di Syam waktu itu.

Pada saat perang siffin berlangsung, pasukan Sayyidina Ali hampir memenangkan peperangan. Namun, karena kelicikan kelompok Muawiyah yang dipelopori oleh Amr bin Ash, Pasukan Sayyidina Ali gagal mendapatkan kemenangan. Kelompok Muawiyah meminta untuk damai dikala mereka telah tersudutkan oleh pasukan Sayyidina Ali. Akhirnya perang berakhir dengan takhkim atau arbitrase. Akhirnya karena mereka meminta perdamaian dengan baik dengan cara mengangkat Al Quran, maka Sayyidina Ali menerima takhkim itu dengan mengirimkan utusan untuk membeuat perjanjian. Karena sikap Sayyidina Ali menerima tahkkim iyu, muncullah kelompok yang tidak mau menerima keputusan itu, karena mereka menganggap hal itu sngat merugikan kubu Sayyidina Ali yang akhirnya dinamakan kelompok Kawarij. Kelpmpok Khawarij yang semula berada pada kubu Sayyidina Ali, akhirnya memisahkan diri dari barisan Sayyidina Ali dan mengaggap baha Sayyidina Ali dan orang-orang yang menerima tahkim dianggapnya kafir. Meskipun begitu, ada juga kelompok yang tetap mendukung Sayyidina Ali yaitu kelompok Syi'ah. Syi'ah sangat menjunjung tinggi Sayyidina Ali. Dari perbedan pendapat ini yang aawalnya hanya masalah politik, akhirnya menjurus kepada teologi. 
Sementara kubu Muawiyah yang akhirnya menjadi pemenang dalam perang siffin melalui tahkim atau arbitrase, mulai mendirikan dinasti baru bernama dunasti Umayyah dan mulai menata kepentingan kekuasaanya. Dari dinasti umayyah inilah akhirnya muncul kelompok yang bernama Jabariyyah. Aliran jabariyyah ini sangat dijunjung tinggi dan dianut oleh dinasti Umayyah. Mereka mengembangkan dan menyebarluaskan paham mereka dikalangan umat Islam. Mereka meyakini bahwa apa yang telah terjadi merupakan takdir dari Allah SWT, temasuk Muawiyah menjadi pemimpin.

Setelah kelompok Jabariyah lahir maka muncullah kelompok yang berbalik dari kelompok Jabariya yaitu kelompok Qodariyah. Kelompok Qodariyah pada saat itu merupakan kelompok Qodariyah pertama yang sangat menjunjung tinggi akal dan merupakan bibit dari kelompok Mu'tazilah. Dari gerakan inilah salah satu murid Muhammad al-Hanafiyah, Washil ibn 'Atha, mengembangkan pemikiran Qadariyah-nya.

Pada saat politik yang sangat kacau dan tidak menentu pada masa itu yang mana orang sangatlah sulit menemukan sebuah kebenaran, ada beberapa orang dari golongan tabi'in yang berpikiran sangat netral dan berpikir jernih dalam menyikapi situasi politik pada masa itu. Kelompok tabi'in yang dipelpori oleh Imam Al-Hasan Al-Bashri, Abu Sufyan Al-Tsauri Fudlalil ibn Liyadi serta Abu Hanifah, mereka menyikapi situasi yang tidak menentu itu dengan cara yang menyejukkan dan sangat bijaksana dalam menyikapinya yaitu dngan cara tetap berada pada jalan yang telah ditentukan oleh Al Quran.

Inilah yang menjadi pondasi utama Ahlussunnah wal jama'ah. Baru kemudian pemikirannya. Diteruskan oleh Abdullah ibn Kullab , Harits ibn Asad Al- Muhasibi, dan Abu Bakar Al- Qolanisi, yang pada abad berikutnya dilanjutkan oleh Abu Al-Hasan Al-Asy'ari dan Abu Al- Mansur Al-Maturidi.

Setelah kekuasaan Bani Umayyah berakhir, maka kekuasaannya berpindah kepada Bani Abbasiyah. Pada masa kekuasaan Bani Abbasiyah, kaum rasional mendapatkan tempat yang tinggi. Bahkan Raja dari Abbasiyah yaitu Harun ar-Rasyid lebih condong kepada Mu'ktazilah. Namun pada kenyataannya, kamum Muktazilah yang selalu mengajak kepada masyarakatnya agar selalu menggunakan akal dan nalarnya malah lebih mengambil sikap irasional. Hingga persoalan-persoalan yang mendasar dan filosofis, semisal "Al- Qur'an itu qadim atau hadis" ditanyakan kepada setiap orang dalam bentuk taftisy (inkuisisi). Dalam situasi kaum Muktazilah yang seperti ini, maka muncullah salah satu tokoh dari kaum Muktazilah yang 
bernama Ali Abu Hasan al-Asy'ari dan mendirikan aliran yang bernama Ahlussunnah wal ajama'ah (A. Sahal, 2015).

Dari perjalanan panjang timbulnya kelompok-kelompok radikal dalam Islam, dalam mencapai tujuannya, kelompok radikal seringkali menggunakan cara-cara kekerasan dan teror. Hal ini menimbulkan kerugian terhadap pihak-pihak yang menjadi target, karena cara mereka yang terkenal sangat ekstrim dan tidak manusiawi. Radikalisme agama merupakan fenomena kegelisahan berlebihan dalam diri seseorang karena pandangan yang pesimis akibat ketidaktahuan pada hukum-hukum agama. Ketidaktahuan ini menimbulkan adanya sikap penolakan terhadap suatu tradisi. Namun, penolakan mereka bukanlah dengan cara yang baik, melainkan dengan cara yang ekstrim dan tidak manusiawi.

Fenomena radikalisme seringkali muncul dengan tindakan-tindakan yang anarki dan tidak manusiawi. Dan yang lebih ironis, kelompokkelompok radikal itu melakukan aksinya dengan mengatasnamakan agama. Baik aksi itu dilakukan anatar kelompok yang berbeda agama ataupun kelompok sesama agama yang mana dalam kelompok sesama agama itu dilakukan karena perbedaan yang dianggap sesat. tindakan radikalisme merupakan tidakan yang meaksakan pendapat, keinginan, dan cita-cita keagamaan dengan jalan yang salah yaitu jalan kekerasan (A. Munip, 2012: 162).

Menurut Rubaidi, ada lima ciri-ciri gerakan radikalisme. Pertama, menjadikan Islam sebagai satu-satunya ideologi yang mengarur kehidupan individu dan tata negara. Kedua, mengadopsi langsung nilai-nilai Islam yang ada di Timur Tengah tanpa mempertimbangkan perkembangan sosial dan politik yang ada pada negara yang ditempati. Ketiga, mereka cnderung memahami Al Quran dan Hadist secara tekstual bukan secara kontekstual, sehingga mereka tidak mengetahui makna yang terkandung dalam isi yang ada pada Al Quran dan Hadist, oleh karenanya mereka sangat selektif dalam memilih budaya lokal. Karena mreka beranggapan bahwa budaya lokal yang berbeda dengan budaya Timur Tengah, meskipun telah bercampur dengan nilai Islam, mereka khawatir itu adalah perbuatan yang bid'ah. Keempat, menolak ideologi Non-Timur Tengah termasuk ideologi Barat, seperti demokrasi, sekularisme dan liberalisme. Kelima, kelompok ini seringkali berbeda pendapat dan keyakinan dengan masyarakat luas termasuk pemerintah (A. Rubaidi, 2010: 63).

Setelah orde baru tumbang, Indonesia merupakan tempat untuk tumbuh suburnya kelompok-kelompok radikal. Sangat banyak kelompok yang berpaham aliran garis keras. Beberapa kelompok itu yaitu: Front 
Pembela Islam (FPI), Forum Umat Islam (FUI), Laskar Jihad, Jama'ah Islamiyah, Majelis Mujahidin Indonesia (MMI), PKS, komite persiapan penerapan syari'ah Islam (KPPSI), dan lain-lain.

Kelompok-kelompok radikal yang sering bermunculan, tidak semuanya lahir di Indonesia, banyak kelompok-kelompok radikal yang lahir di luar Indonesia lalu akhirnya masuk Indonesia dan berkembang didalam negara Indonesia. Usaha kelompok-kelompok radikal dari luar Indonesia untuk mengembngkan paham-paham mereka dan mencapai tujuan mereka, yaitu dengan mendukung kelompo-kelompok radikal lokal/ kelompok radikal yang lahir di Indonesia dan memusnakan berbagai bentuk kelompok yang mengamalkan nilai toleran yang lebih lma dominan di berbagai belahan dunia Islam. Oleh karena itu, kelompok-kelompok radikal yang mengikuti aliran garis keras melakukan penyaringan dalam berbagai bidang baik secara halus maupun secara keras atau kasar (Didin W: 11)

Namun, tidak semua radikalisme itu ditandai dengan aksi-aksi keras yang bersifat anarki. dalam masalah keagamaan, kelompok radikal hanya terbatas mengenai hal tentang ideologi dan pemikiran. Namun, ada juga sebagian kelompok yang mengahalalkan berbagai cara dalam keagamaan, meskipun dengan cara kekerasan. Hal ini membuktikan bahwa dalam masalah keagamaan, kelompok radikal menggunakan dua cara dalam menyebarkan ajaran-ajarannya, yaitu dengan pemikiran atau ideologi yang keras dan tidak menerima berbagai tradisi atau adat yang tidak dicontohkan oleh Nabi Muhammad Saw dan memakai kekerasan dalam menyebarkan ajaran-ajaran mereka.

Dalam akhir-akhir ini, kelompok radikal seringkali melancarkan aksinya dengan cara yang tidak manusiawi. Hal ini dapat dilihat seperti kasus-kasus yang ada di timur tengah seperti, Syiriah, Iran, Palestina, dan beberapa negara Islam lainnya yang tengah dilanda peperangan antar saudara. Ini terjadi akibat kerasnya sikap mereka yang tidak mau saling mengalah dan mencari jalan tengah.

Salah satu kelompok radikal yang berada di Timur tengah yaitu ISIS (Islamic State in Iraq and Syria). Kelompok ini merupakan kelompok yang bersenjata dan mengatasnamakan Islam yang wilayah kekuasaannya berpusat di Suriah Timur dan Irak Utara dan Barat. Banyak negara yang mengecam aksi mereka, bukan hanya negara yang didominasi oleh penduduk non-Islam, melainkan negara yang didominasi oleh penduduk Islam sendiri melakukan pengecaman terhadap aksi-aksi mereka yang sangat tidak manusiawi. Strategi mereka yang sangat brutal dalam menjalankan misi dan tujuannya yaitu dengan melakukan pembunuhan 
massal dan melakukan penculikan yang digunakan sebagai tawanan dan anggotanya. Selain itu mereka juga tidak segan-segan membunuh para wartawan yang sedang meliputnya dengan cara memenggal kepalanya. Karena aksi mereka itulah banyak negra yang mengecam aksinya. Tidak hanya mengecam saja, bahkan negara-negara tersebut membantu dengan mengirim pasukan untuk menyerang balik pasukan ISIS dan juga memberikan bantuan berupa makanan dan kebutuhan-kebutuhan lainnya seperti obat-obatan, pakaian, tenda sebagai rumah sementara, dan lain sebagainya.

Tujuan dari kelompok ISIS ini adalah ingin mendirikan sebuah khilafah, dimana seluruh kepemimpinan berpusat pada satu titik dari seluruh belahan dunia. Mereka ingin kembali seperti ketika kepemimpinan Nabi Muhammad Saw dan para sahabat yang mana seluruh dunia hanya dipimpin oleh satu pemimpin. Untuk mencapai tujuan itu, mereka memaksakan keinginan itu dengan melakukan aksi kekerasan.

Di Indonesia, pernah ada kelompok radikal yang sampai saat ini masih dikenal oleh seluruh rakyat Indonesia yaitu PKI. PKI merupakan singkatan dari Partai komunis Indonesia. Kelompok ini, awalnya merupakan kelompok politik, namun setelah tahun 1965, kelompok ini secara resmi dibubarkan. Kelompok radikal nomor tiga terbesar didunia ini, stelah Rusia dan Tiongkok, harus dibubarkan karena aksinya yang sampai saat ini dikenal dengan aksi G30S/PKI. Dikatakan G30S/PKI, karena mereka melakukan aksinya pada tanggal 30 september. Mereka melakukan aksi tersebut dengan membunuh para Jendral dan umat Islam dengan cara yang tragis.

Kelompok-kelompok radikal yang menggunakan aksi kekerasan merupakan sejumlah kecil dari sebagian besar umat umat Islam. Akibatnya dari fenomena radikalisme yang dilakukan oleh sebagian kecil dari jumlah umat Islam ini, oleh masyarakat barat yang sangat membenci Islam masalah ini, lebih di besar-besarkan. Sehingga media internasional, membuat opini, bahwa Islam merupakan agama yang mengerikan karena suka akan peperangan dan kekerasan. hal ini mengakibatkan banyak yang berpikiran negatif tentang agama Islam. Hal ini dapat di buktikan dengan adanya poster, gambar, dan vidio yang memojokkan agama Islam. Tentu saja hal ini sangat merugikan agama Islam yang pada hakikatnya agama Islam sangatlah menjunjung tinggi nilai perdamaian dan kasih sayang.

\section{Pendidikan Agama Islam Berbasis Nahlatul Ulama'}

Dalam merumuskan arti pendidikan, para ahli pendidikan menemui kesulitan. Kesulitan itu antara lain di sebabkan oleh banyaknya jenis 
kegiatan serta aspek kepribadian yang di bina dalam kegiatan tersebut, karena kegiatan tersebut dapat diartikan pendidikan. Dengan kata lain karena kesulitan itu disebabkan oleh banyaknya kegiatan dan banyaknya kepribadian yang harus di bina oleh pendidikan (A. Tafsir, 2017: 5). Menurut John Dewey, pendidikan adalah suatu proses untuk membentuk kemampuan yang fundamental, baik menyangkut daya pikir (intelektual) maupun daya perasaan (emosional), menuju ke arah tabiat manusia (M. Arifin, 2010: 3).

Pendidikan dapat juga diartikan sebagai latihan mental, moral, dan fisik yang dapat menumbuhkan kepribadian yang tinggi dan menanmkan tanggung jawab (H.M. Arifin, 2016: 7). Pendidikan bagaikan makanan pada manusia yang memberi asupan gizi dan tenaga agar dapat bertahan hidup. Oleh karena itu, manusia juga harus mendapatkan pendidikan yang cukup dan sesuai, sehingga ia dapat menjadi manusia seutuhnya. Peran pendidikan sangatlah penting untuk menentukan keberadaan dan perkembangan manusia. Oleh karena itu pendidikan sangat diperlukan untuk menjadikan manusia yang sempurna. Namun tidak ada satupun di dunia ini yang di dunia ini yang dapat mencapai sebuah kesempurnaan tanpa adanya suatu proses yang panjang.

Beberapa para ahli berpendapat bahwa pendidikan memiliki arti sebagai berikut:

a. Rupert C. Lodge dalam Philosopy of Education berpendapat bahwa pendidikan dalam arti yang luas itu meyangkut seluruh pengalaman dan dalam arti yang luas, kehidupan adalah sebuah pendidikan dan pendidikan adalah kehidupan itu sendiri (A. Tafsir, 2017: 5).

b. Mortimer J. Adler lebih mengartikan pendidikan adalah sebuah proses dimana semua kemampuan manusia baik bakat dan kemampuan yang dimiliki dan diperolehnya yang dapat mempengaruhi oleh sebuah pembiasaan yang disempurnakan melalui kebiasaan-kebiasaan yang baik untuk mencapai suatu tujuan yang ditetapkan, yaitu kebiasaan yang baik (M. Arifin, 2010: 3).

c. Herman H. Home mengartikan pendidikan sebagai suatu proses penyesuaian diri dengan lingkungan sekitarnya (M. Arifin, 2010: 3).

Dari beberapa pendapat diatas, dapat disimpulkan bahwa pendidikan adalah suatu proses untuk menumbuhkan dan meningkatkan pengetahuan melalui pengalaman yang di dapatkan di alam sekitar. Pendidikan juga dapat diartikan sebagai upaya membentuk dan mengembangkan ketrampilan, pengetahuan, dan kebiasaan untuk mencapai suatu tujuan yang akan dicapai. Tujuan pendidikan bila dipandang sebagai suatu proses, 
maka akan berakhir ketika tujuan itu telah dicapainya. Tujuan pendidikan pada hakikatnya adalah suatu perwujudan dari nilai-nilai yang telah terbentuk dalam pribadi manusia yang diinginkan.

Bila dikaitkan dengan Islam, maka pendidikan Islam menurut Prof. Omar Muhammad Al-Touny al-Syaebani yaitu sebagai usaha untuk mengubah pribadi yang ada pada kehidupan individu atau kehidupan masyarakat dan kehidupan alam sekiyatrnya yang dilandasi dengan nilainilai yang islami. Sedangkan Pendidikan Islam sesuai dengan rumusn seminar pada tahun 1960, mengartikan bahwa Pendidikan Islam yaitu sebagai upaya untuk membimbing terhadap pertumbuhan seseorang baik secara jasmani maupun rohani yang sesuai dengan ajaran Islam melalui hikmah sebagai alat untuk mengarahkan, mengasuh, melatih, mengajarkan, mengawasi berlakunya semua ajaran Islam (M. Arifin, 2010: 3).

Dalam pandangan Islam, manusia merupakan manusia paling sempurna yang diciptakan oleh Allah SWT yang didalamnya diberi kelengkapan kelengkapan psikologis dan fisik sehingga manusia mampu untuk membedakan antara perilaku yang baik dan perilaku yang buruk. Cara membedakan antara perilaku yang baik dan perilaku yang buruk, yaitu dengan melalui peroses pendidikan. Karena dengan mereka memiliki pendidikan, mereka dapat mengetahui antara yang baik dan buruk.

Nahdlatul Ulama' adalah sebuah jam'iyyah atau organisasi yang berpaham Ahlussunnah wal Jama'ah. Nahdlatul Ulama' juga sebuah lembaga yang mempertahankan budaya dan tradisi keagamaan yang dianut jauh sebelumnya.

Mengenai terma Ahlussunnah wal Jama'a, beberapa Ulama' berbeda pendapat. Ada yang berpendapat bahwa Ahlussunnah wal Jama'ah muncul setelah Nabi Muhammad SAW wafat. Kata Ahlussunnah wal Jama'ah berarti sekolompok golangan yang mengikuti sunnah nabi Muahmmad Saw. Oleh karena itu sangat banyak kelompok-kelompok yang mengaku Ahlussunnah wal Jama'ah, namun dalam prakteknya mereka jauh dari ajaran-ajaran Nabi Muhammad Saw.

Latar belakang berdirinya NU adalah upaya mempertahankan ajaran Islam Ahlussunnah wal Jama'ah dan memperjuangkan kemerdekaan Indonesia dari kekuasaan penjajah (Tim Aswaja, 2016: 407). Nahdlatul Ulama' dari awal hingga kini tepap mempertahankan ajaran Ahlussunah wal Jama'ah. Karena Nahdhatul Ulama' dalam hal teologi, aqidah, syariah dan akhlaq yang mengikuti pada pola pemikiran Abu Hasan Al Asy'ary (Asy'ariyah) dan Abu Mansur Al Maturidi (Maturidiyah) Dalam hal fiqih mengikuti empat madzhab yang diikuti oleh mayoritas umat Islam yaitu 
imam Syafi'i, Imam Maliki, Imam Hanbali dan Imam Hanafi. Sedangkan dalam hal tashawuf, Nahdlatul Ulama' mengikuti Imam Junaid al Baghdadi (Al Junaidi) dan Imam Al Ghazali (Fathurrohman, 2012: 37). Maka tak perlu diragukan lagi bagaimana Nahdlatul Ulama' dalam menyikapi tradisi-tradisi yang menurut kelompok lain adalah sesat.

Nahdlatul Ulama' seringkali mendapatkan tuduhan-tuduhan bahwa tradisi keagamaan yang dilakukan oleh Nahdlatul Ulama' adalah bid'ah dan semua yang bid'ah adalah sesat. Pemahaman yang salah inilah akhirnya yang menimbulkan suatu tidakan-tindakan yang berujung pada perbuatan radikal. Berbeda dengan Nahdlatul Ulama' yang melakukan suatu tradisi itu, karena Nahdlatul Ulama' telah mengetahui dasar dasar dari suatu tradisi yang dilakukannya. Nahdlatul Ulama' yang berpegang teguh pada paham Ahlusunnah wal Jama'ah memiliki watak yang halus dan fleksible dalam menghadapi dan melakukan sesuatu. Sehingga Nahdlatul Ulama' bukanlah sebuah oraganisasi yang keras dan berujung pada perbuatan yang radikal.

\section{Menangkal radikalisme melalui nilai-nilai Ahlussunnah wal Jama'ah}

Dalam konteks kemasyarakatan atau sosial, Nahdlatul Ulama' yang berlandaskan Ahlussunnah wal Jama'ah berpangkal pada landasan pokok yaitu tawasuth (moderat), tawasuh (toleran), tawazun (seimbang), Al'Adalah (keadilan), dan amar ma'ruf nahi munkar (mendorong pada perbuatan baik dan mencegah pada perbuatan yang buruk) (Fahmi, 2013: 3). Dari landasan pokok ini memberikan pengajaran pada generasi Nahdlatul Ulama' untuk bersikap yang kritis terhadap suatu realitas, dapat menerima suatu perbedaan yang adil dan seimbang, dan bersikap yang moderat.

Tujuan dari pendidikan Aswaja dalam (Wahyudin) antara lain:

a. Menumbuhkan aqidah ahlussunnah wal jama'ah melalui pemberian, pemupukan, dan pengembangan pengetahuan, penghayatan, pengamalan, pembiasaan, serta pengalaman kepada peserta didik tentang nilai-nilai ahlussunnah wal jama'ah sehingga mereka mampu untuk menjadi muslim yang senantiasa meningkatkan keimanan dan ketaqwaan kepada Allah SWT sesuai dengan landasan Ahlussunnah wal jama'ah.

b. Menjadikan pribadi umat Islam yang taat beragama serta berakhlakul karimah yaitu umat yang memiliki pengetahuan yang luas, rajin dalam beribadah, cerdas, produktif, etis, jujur dan adil (tawassuth dan i'tidal), berdisiplin, berkesimbangan (tawazun), bertoleransi (tasamuh), selalu menjaga keharmonisan secara individu/personal dan sosial kemasyarakatan serta mengembangkan budaya Ahlussunnah wal- 
Jama'ah (amar ma'ruf nahi munkar) dalam komunitas madrasah dan masyarakat.

Nilai-nilai Nahdlatul Ulama' tentang tawasuth (moderat), tawasuh (toleran), tawazun (seimbang), Al-'Adalah (keadilan), dan amar ma'ruf nahi munkar (mendorong pada perbuatan baik dan mencegah pada perbuatan yang buruk), menunjukkan bahwa Nahdlatul Ulama' sangat toleran terhadap berbagai adat dn tradisi. Bahkan tidak sampai disitu, warga Nahdlatul Ulama' juga menjunjung tinggi dan melestarikan adat dan tradisi umat Islam yang ada di Indonesia, meskipun oleh kelompok lain dianggap menyimpang dari syari'at Islam. Selain itu, warga Nahdlatul Ulama' juga mau membuka diri dengan cara menerima diskusi mengenai hal-hal yang bertentangan dan orang-orang yang berbeda agama dan budaya. Dengan cara seperti ini, dapat memungkinkan seseorang untuk tertarik dengan ajaran-ajaran Islam sehingga mereka mau masuk ke dalam agama Islam. Berbeda dengan kelompok radikal yang lebih berpikir kaku dan tidak toleran sama sekali, mereka lebih cenderung menggunakan kekerasan dan bahasa yang kasar dalam menilai mereka yang berbeda pendapat bahkan orang yang berbeda agama sekalipun. Sehingga mereka menganggap bahwa agama Islam adalah agama yang tertutup, keras, dan meyukai kekerasan. padahal agama Islam merupakan agama yang Rahmatan lil 'Alamin, agama yang sangat menjunjung tinggi toleransi, dan agama yang membawa perdamaian bagi seluruh makhlup yang ada di dunia ini.

Pendidikan yang berbasis Nahdlatul Ulama' merupakan sebuah pendidikan yang berasaskan Ahlussunnah wal Jama'ah, yang memiliki nilainilai sangat fleksible dalam mengahadapi segala situasi dan kondisi didalam masyarakat. Nahdlatul Ulama' merupakan kelompok yang dikenal tidak kaku dan cenderung lembut dalam masyarakat Indonesia. Bahkan dengan adanya Nahdlatul Ulama' di Indonesia, Indonesia menjadi contoh dunia. Dimana Indonesia merupakan negara plural dan sangat multikultural, namun masih tetap menjunjung tinggi nilai toleransi atas perbedaanperbedaan yang ada di Indonesia.

Oleh karena itu, peran pendidikan berbasis Nahdlatul Ulama sangat penting di Indonesia. Mengingat Indonesia yang terdapat banyaknya perbedaan suku, ras, budaya, dan agama. Tidak hanya itu, organisasi masyarakat di Indonesia juga sangat banyak, terlebih organisasi agama Islam. Munculnya banyaknya organisasi ini, apabila tidak diimbangi dengan nilai-nilai Ahlussunnah wal Jama'ah yang sangat fleksible dalam menghadapi situasi dan gesekan-gesekan yang ada di Indonesia, maka akan terjadi keributan-keributan dan juga konflik-konflik antar warga Indonesia. Oleh 
karena itu, hadirnya Nahdlatul Ulama' memberikan nilai-nilai Ahlussunnah wal Jama'ah turut menjaga persaruan dan kesatuan Negara kesatuan Republik Indonesia.

Karena Nahdlatul Ulama, selain mengamalkan nilai-nilai keagamaan, juga turut melestarikan tradisi dan budaya yang ada di indonesia dengan memberikan nafas yang Islami sehingga tidak menyingkur dan bertentngan dengan agama Islam.

\section{Kesimpulan}

Radikalisme adalah sebuah pahan yang menuntut adanya sebuah perubahan atau pembaharuan secara langsung. Dalam sejarah Islam, radikalisme pertama kali muncul dari kelompok khawarij. Karena khawaijlah yang pertama kali menanamkan bibit-bibit radikalisme. Hal ini timbul karena sikap khawarij yang terlalu berlebihan membenci pada Sayyidina Ali dan beberapa sahabat pada saat perang siffin. Bahkan mreka menganggap bahwa para sahabat yang mnyetujui perdamaian dalam perang itu dianggapnya sebagai kafir. Sikap radikal mereka juga dibuktukan dengan mereka memaksakan pendapatnya agar disetujui oleh pihak lain.

Ada lima ciri-ciri gerakan radikalisme. Pertama, menjadikan Islam sebagai satu-satunya ideologi yang mengarur kehidupan individu dan tata negara. Kedua, mengadopsi langsung nilai-nilai Islam yang ada di Timur Tengah tanpa mempertimbangkan perkembangan sosial dan politik yang ada pada negara yang ditempati. Ketiga, mereka cnderung memahami Al Quran dan Hadist secara tekstual bukan secara kontekstual, sehingga mereka tidak mengetahui makna yang terkandung dalam isi yang ada pada Al Quran dan Hadist, oleh karenanya mereka sangat selektif dalam memilih budaya lokal. Karena mreka beranggapan bahwa budaya lokal yang berbeda dengan budaya Timur Tengah, meskipun telah bercampur dengan nilai Islam, mereka khawatir itu adalah perbuatan yang bid'ah. Keempat, menolak ideologi Non-Timur Tengah termasuk ideologi Barat, seperti demokrasi, sekularisme dan liberalisme. Kelima, kelompok ini seringkali berbeda pendapat dan keyakinan dengan masyarakat luas termasuk pemerintah.

Kelompok-kelompok radikal yang sering bermunculan, tidak semuanya lahir di Indonesia, banyak kelompok-kelompok radikal yang lahir di luar Indonesia lalu akhirnya masuk Indonesia dan berkembang didalam negara Indonesia. Untuk menangkal adanya sebuah radikalisme, maka diperlukan adanya pendidikan. Karena pendidikan merupakan proses manusia dalam mengetahui antara perbuatan yang baik dan perbuatan yang buruk. Dalam 
pandangan Islam, manusia merupakan manusia paling sempurna yang diciptakan oleh Allah SWT yang didalamnya diberi kelengkapan kelengkapan psikologis dan fisik sehingga manusia mampu untuk membedakan antara perilaku yang baik dan perilaku yang buruk. Cara membedakan antara perilaku yang baik dan perilaku yang buruk, yaitu dengan melalui peroses pendidikan. Karena dengan mereka memiliki pendidikan, mereka dapat mengetahui antara yang baik dan buruk.

Salah satu pendidikan yang dapat memberikan nilai-nilai dalam menangkal faham radikalisme adalah pendidikan Islam berbasis nahdlatul Ulama'. Karena pendidikan Islam berbasis nahdlatul Ulama'memberikan nilai lebih pada sebuah pendidikan. pendidikan Islam berbasis nahdlatul Ulama' fleksible dalam mengahadapi sebuah situasi dan kondisi yang ada dalam masyarakat. Dalam konteks kemasyarakatan atau sosial, Nahdlatul Ulama' yang berlandaskan Ahlussunnah wal Jama'ah berpangkal pada landasan pokok yaitu tawasuth (moderat), tawasuh (toleran), tawazun (seimbang), Al-'Adalah (keadilan), dan amar ma'ruf nahi munkar (mendorong pada perbuatan baik dan mencegah pada perbuatan yang buruk). Dari landasan pokok ini memberikan pengajaran pada generasi Nahdlatul Ulama' untuk bersikap yang kritis terhadap suatu realitas, dapat menerima suatu perbedaan yang adil dan seimbang, dan bersikap yang moderat. Oleh karena itu, peran pendidikan berbasis Nahdlatul Ulama sangat penting di Indonesia. Mengingat Indonesia yang terdapat banyaknya perbedaan suku, ras, budaya, dan agama. Tidak hanya itu, organisasi masyarakat di Indonesia juga sangat banyak, terlebih organisasi agama Islam.

\section{Saran}

Untuk penelitian selanjutnya, penulis menyarankan agar lebih fokus kepada tujuan-tujuan kelompok radikal. Penelitian yang difokuskan pada tujuan-tujuan kelompok radikal tersebut guna mengetahui langkah-langkah yang lebih tepat dalam menangkal radikalisme. Meskipun dalam penulisan ini telah disebutkan bahwa pendidikan Islam berbasis Nahdlatul Ulama' dapat menangkal radikalisme, namun masih banyak kekurangan dalam hal penulisan. Begitu juga dalam menangkal radikalisme, masih banyak cara agar radikalisme yang ada di Indonesia, bahkan di dunia sekalipun dapat dihapuskan dengan cara-cara yang lebih tepat, dengan mengetahui lebih dalam tujuan tujuan kelompok yanh menganut faham radikalisme. 


\section{Referensi}

Arifin, H.M. Ilmu Pendidikan Islam. Edited by Fauzan Asy. Ke-VII. Jakarta: PT Bumi Aksara, 2016.

Arifin, Muzayyin. Filsafat Pendidikan Islam. V. Jakarta: PT Bumi Aksara, 2010.

Dendy Sugono. Kamus Bahasa Indonesia. Jakarta: Pusat Bahasa, 2008.

Fahmi, Muhammad. "Pendidikan Aswaja NU Dalam Konteks Pluralisme" 1 (2013).

Fathurrohman. "Aswaja NU Dan Toleransi Umat Beragama." Jurnal Review Politik 2, no. 1 (2012): 34-45.

Fuad, A Jauhar. "PEMBELAJARAN TOLERANSI Upaya Guru Pendidikan Agama Islam Dalam Menangkal Paham Radikal Di Sekolah" 9, no. 2 (2018): 561-571.

JATIM, Tim Aswaja NU Center PWNU. Khazanah Aswaja. Edited by Ahmad Muntaha AM. Surabaya: ASWAJA NU Center PWNU JATIM, 2016.

Rubaidi, A. Radikalisme Islam, Nahdlatul Ulama: Masa Depan Moderatisme Islam Di Indonesia. Yogykarta: Logung Pustaka, 2010.

Sahal, Akhmad. Islam Nusantara: Dari Ushul Fiqih Hingga Paham Kebangsaan. Bandung: Mizan Pustaka, 2015.

Tafsir, Ahmad. Metodologi Pengajaran Agama Islam. Edited by Mukhlis. 13th ed. Bandung: PT Remaja Rosdakarya, 2017.

Wahyudin, Didin. "PENDIDIKAN ASWAJA SEBAGAI UPAYA MENANGKAL RADIKALISME” (n.d.): 291-314.

"Menangkal Radikalisme Agama Di Sekolah." Jurnal Pendidikan Islam 1, no. 2 (2012): 159-181. 